\title{
WHY VILLAGE FUND NOT YET PROMOTING ENVIRONMENTAL SUSTAINABILITY? AN EMPIRICAL STUDY OF VILLAGE FUND INCENTIVES IN CENTRAL JAVA PROVINCE, INDONESIA
}

\author{
Djuwityastuti, Wida Astuti \\ Faculty of Law, Universitas Sebelas Maret \\ E-mail: widaastuti_60@yahoo.coid
}

\begin{abstract}
One of the purposes of granting village funds under Village Law Number 6 of 2014 is to support the rural development through the sustainable use of natural and environmental resources. Based on the statistical data from The Ministry of Finance Republic of Indonesia, the grant of village funding since 2015 has increased for each year. However, based on empirical data in The Central Java Province is still in the allocation for physical development (infrastructure sector) and far from environmental sustainability programs. Through research funded by SebelasMaret University Surakarta, this article will describe (1) factors that hinder the sustainable environmental development and (2) how the way out that can be applied to support sustainable environmental development for subsequent years.
\end{abstract}

Keywords: Village fund, Environmental sustainability

\section{A. INTRODUCTION}

On the theoretical level, under Village Law Number 6 of 2014 is oriented to (1) Improve the welfare and equity of village development through improving public services in the village; (2) Promoting the village economy; (3) Overcoming the inter-village development gap; and (4) Strengthen the village community as the subject of development. In the framework of promoting the village economy, specifically, village funds are expected to be stimulants for the mobilization of the establishment of business fields whose management benefits directly or indirectly to villages based on the principles of fairness, priority needs and village typology.

In order to support the development of the village, the government of Indonesia provides incentives of village funds that are distributed since 2015. Referring to the existing data is known that The Central Java Province is getting the largest allocation of village funds among the provinces in Indonesia. The 
amount of village funds received by The Central Java Province in the last two years can be seen in the following table (Ministry of Finance, 2017)

\begin{tabular}{|c|c|}
\hline \multicolumn{2}{|c|}{ Fund (in Indonesian Rupiah) } \\
\hline 2016 & 2017 \\
\hline $8,373,021,018,000$ & $6,384,442,058,000$ \\
\hline
\end{tabular}

(Table 1:The Central Java Province Village Fund)

However, based on the facts which are found during this research indicating that all village funds received, the majority of village funds are still allocated to village infrastrucuture development activities such as roads, buildings, and water supply improvements. Of course this condition clashed with the philosophy, principles and objectives of granting the Village Fund as mandated by Law Number. 6 of 2014. Referring to the historical perspective, the academic paper on the establishment of Law Number. 6 of 2014 emphasized aspects of the effectiveness and transparency of village financial finances as a stimulant to extract the sources of village funding, because in the government regime before the Village Act there was no village have the authority and capacity to explore the potential of village financial resources.

\section{B. PROBLEM STATEMENT}

In accordance with the theme above, this research focuses on describing (1) what is the factors that hinder the sustainable environmental development and

(2) what is the suitable solutions that can be applied to support sustainable environmental development for subsequent years.

\section{RESEARCH METHODS}

This type of research is empirical research, therefore the relevant and effective design used is to use the model of Simple Research Model below (Punch, 2000). 


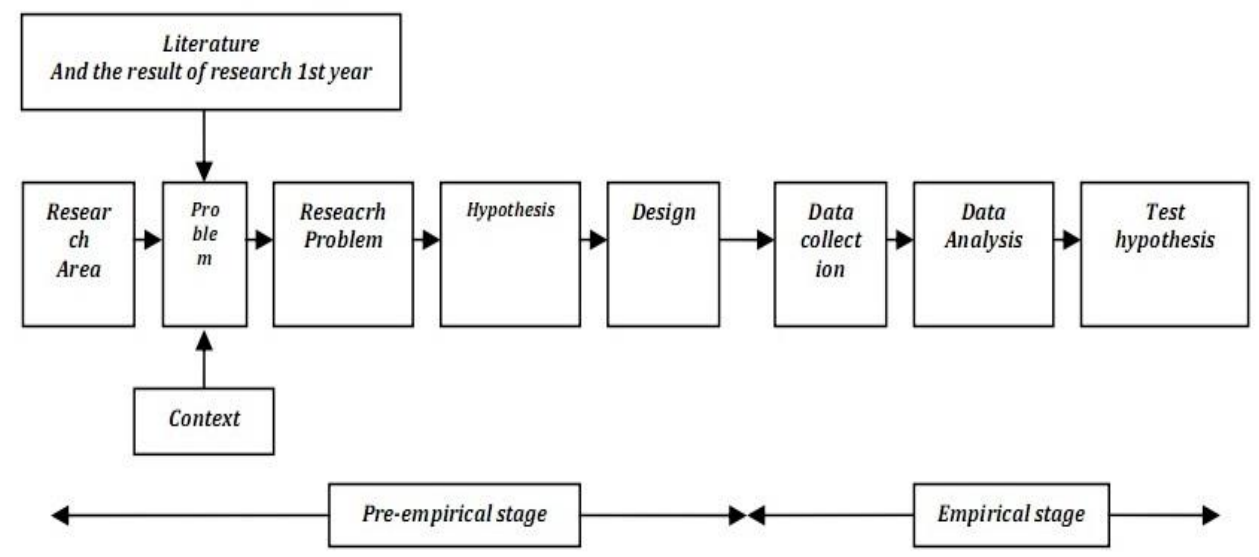

The research data is divided into two sources, the first or the primary data obtained from the observation, problem exploration, problem identification, and mapping of existing conditions, Focus Group Discussion (FGD) in selected municipalities in The Central Java Province. while the second research data obtained from books and references that support research activities. Data validity is done by triangulation of data, that is data which have been obtained from a source compared with data from other. As for the secondary data source criticism do, i.e with steps to listen, assess and record.

\section{DISCUSSION AND RESEARCH RESULT}

From research conducted from March to October 2017, it can be seen that the factors causing sustainable environmental development programs cannot be implemented because of several factors, namely (1) the paradigm of village funds is a gift, (2) lack of government direction, and (3) lack of village innovation and community involvement, whereas for each factor can be explained as follows.

\section{HINDERING FACTORS}

a. The paradigm of village funds is a gift

So far the village considers that the village fund is a gift. The consequence of this paradigm raises the next problem, among others, assume that the accountability of village finances is a formality only, leaving the community involvement and ending in the corruption behavior committed by the village apparatus. In the process of research found false evidence of expenditure, markup project funds from the standard price and corruption behavior between the village government with the implementer of infrastructure projects. The facts found at the time of the research, indirectly 
corroborate the argument that corrupt behavior will indirectly hamper sustainable environmental development programs (Morse, 2006).The data found at the time of the research is in line with the publication of the Corruption Eradication Commission (KPK). From a review conducted in January 2015 on village fund management, the Corruption Eradication Commission (known as KPK) found 14 problems in four aspects: regulatory and institutional aspects; governance aspects; supervision aspects; and aspects of human resources. One interesting point to observe from the review of the KPK mentioned above is that the preparation of the Village Revenue and Expenditure Budget does not fully reflect the priority needs of the village so it is feared that the progress of village development will stagnate (slowdown) in the long term. In the same context, the results of the Financial and Development Supervisory Agency (BPKP) study indicate that the amount of village funds received by villages across Indonesia raises concerns for many. There are various potential errors in the use of village funds ranging from budgeting, implementation, administration, accountability, to reporting

\section{b. Lack of government direction}

In addition to having the right to fully regulate their own household affairs, the Village also has an obligation to realize the objectives of village management such as improving public services for the villagers to accelerate the realization of general welfare, promote the economy of rural communities and overcome the national development gap and strengthen the village community as subjects development. To realize its objectives, the village is deemed necessary to carry out various strategies. This strategy is important so that the allocations, potentials and resources in the village can be streamlined to support the realization of sustainable village development. Based on the facts found in research, the role of central government and local governments in guiding village governance, particularly in relation to programs aimed at sustainable environmental development has not been explained optimally. so far the local government has only given direction on how the village funds are well managed and accountable, but it is not explained in detail what programs should be implemented in the framework of realizing sustainable environmental development.

\section{c. Lack of village innovation and community involvement}

The use of village funds must be accompanied by the development of a creative economy based on innovation. Therefore, innovation should not stop because the creativity of the village community will give birth to superior products by utilizing the potential of the village. So that the village economy will continue to grow and develop, further creativity-based programs should 
involve community participation. Refers to Creighton thinking (Creighton, 2005) then the ideal ideas that can be drawn from community participation in community-based sustainable environmental-based development programs are (1) Public participation is based on a belief that anyone has the right to engage in sustainable environmental development programs. (2) Public participation encompasses a commitment or promises that the contribution of ideas and ideas on sustainable environmental development programs derived from each member of the community can affect the policies and/or villages regulations issued. (3) Public participation promotes sustainable decisions by acknowledging and communicating the will and interests of all societies in relation to sustainable environmental development programs, including the interests and desires of decision makers in a balanced way.

2. Framework Of Realizing Sustainable Environmental Development Using Village Funds

By looking at the facts discovered during the course of the research, the suitable solutions that can be applied to improve the sustainable environmental development programs can be illustrated as follows.

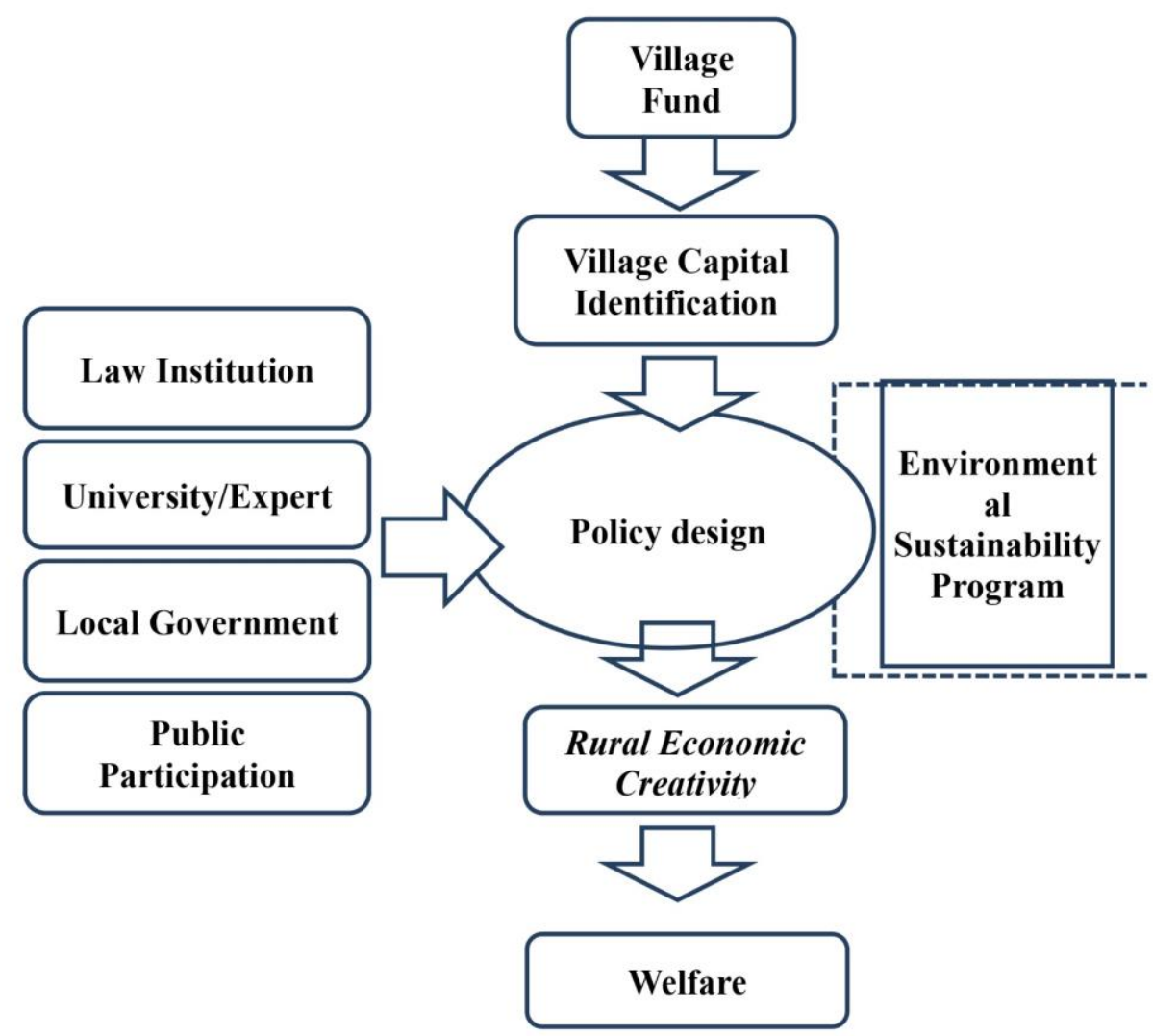


From the illustration above it can be explained that the key to the successful implementation of programs within the framework of realizing sustainable environmental development using village funds lies in cooperation to strengthen each other between the villages by actively involving the community, support and guidance from the local government as well as involvement of the role of universities. The equal partnership of the four parties in formulating the policy as the basis for the preparation of the program is based on the strength and potential of the village's wealth. Effective participation of the community elements in a series of process-making programs that support sustainable environmental development requires a binding agreement, including the formulation of issues and agendas, every society should have a balanced and adequate opportunity to express its preference for achieving results end.

This is where the strategic and active role of universities in "helping" the weaknesses of the village in an effort to utilize the available village funds as a stimulant of the realization of programs that support sustainable environmental development, as well as able to bridge the formulation of a more adaptive policy to the issue of global change. The importance of village government collaboration with universities is the best way out as Mahroum recommends "policy makers should work with appropriate universities and colleges to transfer 'hands-on' expertise and training to local communities. In areas without such institutions, technical colleges could use similar techniques to help foster rural innovation ". (Mahroum, et all, 2007).

In addition to involving universities, government and public participation, so that the use of village funds can be used with transparent and avoid abuse, it is necessary to work together with law institutions such as prosecutors and police. Therefore the policies made by involving the above four elements, are expected to produce participatory and simultaneous village-funded governance-based programs that can ultimately benefit the community, especially the creation of community welfare.

\section{E. CLOSING}

As a stimulant fund that aims to improve the welfare of the community, village funds must be managed with transparency and accountability. related to the issue of sustainable development, it is found that the majority of village development does not have programs that support sustainable environmental development because of three causes, namely (1) the paradigm of village funds is a gift, (2) lack of government direction, and (3) lack of village innovation and community involvement. Through this article, in order that village-run programs can support sustainable environmental development, strong collaboration between local 
governments, universities, communities and law enforcement agencies is required. the four elements with their respective contributions are expected to provide benefits, especially for realizing community welfare.

\section{BIBLIOGRAPHY}

Creighton, James L, 2005, The Public Participation Handbook: Making Better Decisions Through Citizen Involvement, John Wiley \& Sons, Inc: San Francisco:

Ministry of Finance, 2016, Lampiran Rincian Alokasi Dana Desa Tahun Anggaran 2017, Kementrian Keuangan: Jakarta

Mahroum, Sami et all, 2007, Rural Innovation, Nesta: London.

Morse, S, 2006, Is corruption bad for environmental sustainability?, a cross-national analysis. Ecology and Society 11(1): 22.

Punch, Keith F, 2000, Developing Effective Research Proposals Essential Resources for Social Research, Sage Publications: London. 